\title{
Comparison of 3 Different Bupivacaine Concentrations Used in the Ultrasound Guided Infraclavicular Brachial Plexus Block
}

\author{
Semih Başkan $\oplus^{\oplus}$ \\ Fahri Acar $\odot$ \\ Gökhan Demirelli $\odot$ \\ Hidayet Unal ๑
}

\author{
Ultrasonografi Eşliğinde Infraklaviküler Brakial \\ Pleksus Blok Uygulamasında Kullanılan 3 Farklı \\ Bupivakain Konsantrasyonunun Karşılaştırılması
}

\begin{abstract}
Objective: This double-blinded, randomized, prospective study compared 3 different concentrations of bupivacaine using the same total volume for ultrasound-guided infraclavicular block applied in the upper extremity surgery.

Methods: This clinical trial was conducted on 150 patients aged between 18-65 years who underwent elbow, forearm, wrist, or hand surgery. The patients were equally and randomly distributed into three groups $(n=50)$. Under ultrasound guidance, the first group received $20 \mathrm{~mL}$ of $0.5 \%$ bupivacaine, the second group $20 \mathrm{~mL}$ of $0.375 \%$ bupivacaine and the third group $20 \mathrm{~mL}$ of $0.25 \%$ bupivacaine injected into the brachial plexus cords. The onset time of sensory and motor block, surgical compliance time (SCT), motor block score at SCT, additional requirement for anesthetic and analgesic agents, sensory and motor block regression time, patient and surgeon satisfaction were recorded.

Results: The onset of sensory block, motor block and SCT were significantly longer in the $0.25 \%$ bupivacaine group than the other groups ( $p \leq 0.05)$. Motor block score at SCT was also lower in the $0.25 \%$ bupivacaine group. The earliest sensory-motor block regression time and requirement for analgesia were recorded in the $0.25 \%$ bupivacaine group. The patient and surgeon satisfaction was not different between groups.

Conclusion: Although $0.25 \%$ bupivacaine concentration is disadvantageous as a result of this data, it can be preferred in patient groups in which full motor block is not wanted due to effective sensory blockade which is important for early postoperative motor examination and planning of physiotherapy.
\end{abstract}

Keywords: Ultrasound-guided infraclavicular brachial plexus block, bupivacain, regional anesthesia, pain management

öz

Amaç: Bu çift kör, randomize, prospektif çalışmada üst ekstremite cerrahisinde ultrason kılavuzluğunda infraklaviküler blok uygulamasında 3 farklı bupivakain konsantrasyonunun karşılaştırılması amaçlandı.

Yöntem: Bu klinik çalışma 18-65 yaşlarında dirsek, önkol, el bileği veya el cerrahisi geçiren 150 hasta üzerinde yapıldı. Hastalar eşit ve randomize olarak 3 gruba ayrıldı $(n=50)$. Birinci gruba 20 $\mathrm{mL} \% 0.5$ bupivakain, 2. gruba $20 \mathrm{~mL} \% 0.375$ bupivakain ve 3. gruba $20 \mathrm{~mL} \% 0.25$ bupivakain uygulandı. Duyusal ve motor blok başlangıç zamanı, cerrahi süresince motor blok skoru, ek anestetik ve analjezik gereksinimi, duyu ve motor blok gerileme zamanı, hasta ve cerrah memnuniyeti kaydedildi.

Bulgular: Duyusal blok, motor blok ve cerrahiye uygunluk süresi başlangıcı \%0.25 grubunda diğer gruplara göre anlamlı olarak daha uzundu ( $p \leq 0.05$ ). Motor blok skoru da \%0.25 bupivakain gruplarında daha düşüktü. En erken duyusal motor blok gerileme zamanı ve analjezik gereksinimi $\% 0.25$ bupivakain grubunda kaydedildi. Hasta ve cerrah memnuniyeti farklı değildi.

Sonuç: Bu veriler sonucunda \%0.25 bupivakain konsantrasyonu dezavantajlı olmasına rağmen, etkili duyusal blokaj nedeniyle tam motor bloğun istenmediği hasta gruplarında tercih edilebilir. Erken postoperatif motor muayeneye olanak vermesi ve fizyoterapi planlanması açısından önemlidir.

Anahtar kelimeler: Ultrasonografi eşliğinde infraklavikular brakial pleksus bloğu, bupivakain, rejyonal anestezi, ağrı yönetimi
Alındığı tarih: 18.02 .2019

Kabul tarihi: 26.03.2019

Yayın tarihi: 30.04 .2019

Atıf vermek için: Başkan S, Acar F, Demirelli G, Ünal H. Comparison of 3 Different Bupivacine Concentrations Used in the Ultrasound Guided Infraclavicular Brachial Plexus Block. JARSS 2019;27(2):94-9.

Semih Başkan Ankara Numune Eğitim ve Araştırma Hastanesi Ankara, Türkiye drsemkan@gmail.com ORCID: 0000-0003-0096-7097

F. Acar 0000-0002-2960-8875 G. Demirelli 0000-0003-4558-9456

H. Unal 0000-0001-5393-0074 Ankara Numune Eğitim ve Araştırma Hastanesi, Ankara, Türkiye 


\section{INTRODUCTION}

The brachial plexus is responsible for entire motor function of the upper extremity and large part of sensory function. Brachial plexus block of interscalene, supraclavicular, infraclavicular, axillary region and terminal nerves can be performed ${ }^{(1)}$.

The brachial plexus in the infraclavicular area is responsible for the innervation of the upper part of the axilla and from the shoulder to the hand the area innervated by the musculocutaneous nerve ${ }^{(2)}$. The indications for infraclavicular brachial plexus block are unilateral upper limb surgery, catheter placement for postoperative relief of pain originating from brachial plexus, treatment of chronic pain of unilateral upper extremity and for sympathetic block ${ }^{(3)}$.

Infraclavicular brachial plexus block is a suitable regional anesthesia technique for hand, wrist and elbow operations and it is usually performed in conjunction with nerve stimulation. However, stimulation of nerve during regional anesthesia is considered to be a blind method. In recent years, with the introduction of ultrasound-guided peripheral nerve blocks, applications and approaches have begun to change. The anatomy of this region, the target nerve or nerves, the vascular structures around the nerve and the lung tissue in the vicinity can be visualized by the ultrasonography ${ }^{(4-6)}$. The infraclavicular brachial plexus blockade constitutes a reliable approach to anesthetize the brachial plexus: Despite similar success rates, it results in a shorter performance time and fewer adverse effects than axillary and supraclavicular brachial plexus block ${ }^{(7)}$. The use of USG improves block success rate, shortens block start time, and reduces side effects and local anesthetic volume.

Bupivacaine is the first local anesthetic which combines its long-acting effect with deep conduction blockage, and distinct separation of sensory block and motor block ${ }^{(8)}$.

Bupivacaine is one of the longest acting anesthetics (3-5 hours). It is three to four times more effective than lidocaine but four times more toxic. Its effect starts within 5-10 minutes. At low concentrations ( $\leq 2.5 \mathrm{mg} \mathrm{mL}^{-1}$ ) it is effective on motor nerve fibers and the duration of action is shorter. However, its low concentrations can be used to reduce postoperative pain ${ }^{(9)}$.

A successful peripheral nerve block depends on the correct identification of nervous structures and the injection of a suitable dose of local anesthetic around them in order to obtain a complete impregnation of all the nerves involved in the surgery. The use of large amounts of local anesthetic increases the chance of systemic toxicity, which is the major complication of regional anesthesia. Although the incidence of systemic toxicity is less than $0.2 \%$, this complication is difficult to treat and potentially fatal ${ }^{(10)}$.

Many studies have shown that successful block can be obtained using $20 \mathrm{~mL}$ local anesthetic. However, the effective local anesthetic dose and concentration are not clear ${ }^{(11-14)}$.

Reducing the local anesthetic concentration may limit the total dose administered without changing the volume injected. However, the minimum concentration of local anesthetic to obtain a safe ICB without compromising the quality and effectiveness of ICB has not been established yet ${ }^{(10)}$.

In this study, we aimed to compare the efficacy of bupivacaine at 3 concentrations and doses in equivalent volume used in ICB in upper extremity surgery. According to our theory, the block made with the higher local anesthetic concentration in the equivalent volume is more effective.

\section{MATERIAL and METHODS}

A hundred and fifty patients undergoing surgery of the elbow, forearm, wrist, or hand were prospectively enrolled after obtaining ethics committee approval, and written informed consent. Inclusion criteria of the patients were determined as age between 18 and 65 years, American Society of Anesthesiologists status 1 to 2 , and body mass index between 20 and $30 \mathrm{~kg} \mathrm{~m}^{-2}$. Exclusion criteria were defined as refusal to participate in the study, existing neuropathy, coagulopathy, neurological or neuromuscular disease, hepatic or renal failure, LA allergy and pregnancy. Randomization was performed in order of arrival. 
Patients were divided into three groups in order of their admission. US-guided ICB was performed in all groups with $20 \mathrm{~mL}$ local anesthetic. Infraclavicular brachial plexus block (ICB) performed with $0.5 \% 20 \mathrm{~mL}$ bupivacaine, in Group 1, 0.375\% $20 \mathrm{~mL}$ bupivacaine in Group 2, and $0.25 \% 20 \mathrm{~mL}$ bupivacaine in Group 3 .

An 18-or 20-gauge intravenous catheter was placed in the premedication room and standard intravenous premedication $\left(0.03 \mathrm{mg} \mathrm{kg}^{-1}\right.$ midazolam and $0.6 \mathrm{mcg}$ $\mathrm{kg}^{-1}$ fentanyl) was administered. All patients underwent single-injection US-guided ICB. No neurostimulation was performed to confirm correct site of needle insertion. Oxygen was delivered through nasal cannulae at $4 \mathrm{~L} \mathrm{~min}^{-1}$, and pulse oximetry were performed during the procedure. ICB was performed in all patients by the same anesthesiologists. For all patients we used $10 \mathrm{~cm}$-long nerve block needles (21G, Locoplex, Vygon, Ecouen, France), portable ultrasound machine (Logiq $\mathrm{E}$, General Electric, USA), and 6- to $13-\mathrm{MHz}$ linear probes.

After asepsis of the skin was achieved and a local infiltration was performed with $1 \mathrm{~mL}$ of $1 \%$ lidocaine, A sterile US probe was applied on the infraclavicular fossa, immediately medial to the coracoid process, to obtain a short-axis view of the axillary artery. Using an in-plane technique, a 21-gauge, $10-\mathrm{cm}$ Tuohy needle was advanced until the tip was located dorsal to the artery. At this place brachial plexus was located at 9, 7 and 5 a clock position. After needle tip was correctly positioned, $20 \mathrm{~mL}$ of bupivacaine was slowly injected. The patient and the surgeon did not know the concentration of the anesthetic agent, and concentration of local anesthetic was prepared by an assistant before the procedure.

Brachial plexus blockade measurements were performed by a single-blind observer at every 5 minutes for 45 minutes. We used 3-point scale cold test: $0=$ no block, 1 = analgesia (patient can feel touch, not cold), and 2 = anesthesia (patient cannot feel touch) for sensory block of the musculocutaneous, median, radial, and ulnar nerves. Sensory block of the nerves was assessed for musculocutaneous (the lateral side of the forearm), median (the volar side of the thumb), radial (the lateral side of the dorsum of the hand) and ulnar (the volar side of the fifth finger) nerves.
Motor function of deltoid, biceps, triceps, flexor (median nerve), extensor (radial nerve), and abductor (ulnar nerve) muscles of the fingers were evaluated by the Modified Bromage scale (Table I).

Table I. Modified Bromage scale degree definition

1. Full strength in relevant muscle groups

2. Strength reduction, but able to move against resistance

3. Ability to move against gravity, but not against resistance

4. Discrete movements (trembling) of muscle groups

We considered the block a success if the sensory block score was $\geq 7$ out of 8 points and the patient was considered to be ready for surgery. Also we recorded motor block score when the patient became ready for surgery.

The same blinded observer examined the patients for the maintenance of surgery without the need for intravenous narcotics, general anesthesia, rescue blocks, or local infiltration.

Postoperative analgesia was assessed in the patient room using a numeric pain rating scale ( 0 : no pain, 10: the worst pain ever experienced and $4 \leq$; rescue analgesic used when requested by the patient at postoperative 24 hour.

\section{Statistical Analysis}

In this study, the primary objective was to estimate the efficacy of bupivacaine at 3 concentrations and doses in equivalent volume used in ultrasoundguided ICB.

Analysis of the data was done using the IBM SPSS 23.0 statistical package program. Chi-square $\left(\chi^{2}\right)$ test was used to compare descriptive statistics and evaluate qualitative data (frequency, percentage, mean, standard deviation, median, and min-max). The normal distribution of the data was evaluated by Kolmogorov-Smirnow and Shapiro-Wilk tests which indicated that the data did not show normal distribution. Kruskal-Wallis test was used for intergroup comparisons. In multiple comparisons, in case of intergroup difference, the Tukey HSD test was used to find out from which groups/groups the difference was originated. A level of $5 \%(c=0.05)$ was considered to be statistically significant. 
Power Analysis: Power analysis G* Power 3.1.9.2 was made with statistical package program; Group number $=3, \alpha=0,05$, Effect size $f=0,3, n=50$ (n1=50, n2=50, n3=50) Power (power (1-beta)) $=0.91$.

\section{RESULTS}

There was no statistically significant difference between the groups in terms of demographic data (p>0.05) (Table II).

Table II. Comparison of patient characteristics between groups [Mean \pm SD - Median (Min/Max)]

\begin{tabular}{|c|c|c|c|c|}
\hline & $\begin{array}{l}\text { Group I } \\
(n=50)\end{array}$ & $\begin{array}{l}\text { Group II } \\
(n=50)\end{array}$ & $\begin{array}{c}\text { Group III } \\
(n=50)\end{array}$ & $p$ \\
\hline Age & $\begin{array}{l}36.1 \pm 13.8 \\
36(18 / 65)\end{array}$ & $\begin{array}{l}35.1 \pm 15.7 \\
32(18 / 65)\end{array}$ & $\begin{array}{c}38.3 \pm 14.5 \\
37.5(18 / 65)\end{array}$ & 0.414 \\
\hline $\begin{array}{c}\text { Gender Female } \\
\text { Male }\end{array}$ & $\begin{array}{l}17(34 \%) \\
33(66 \%)\end{array}$ & $\begin{array}{l}13(26 \%) \\
37(74 \%)\end{array}$ & $\begin{array}{l}17(34 \%) \\
33(66 \%)\end{array}$ & 0.609 \\
\hline BMI & $\begin{array}{c}24.9 \pm 2.9 \\
25(19.5 / 29.8)\end{array}$ & $\begin{array}{c}24.5 \pm 3.2 \\
24.7(18.5 / 29.6)\end{array}$ & $\begin{array}{c}25.0 \pm 2.4 \\
25.2(20.2 / 29)\end{array}$ & 0.751 \\
\hline $\begin{array}{l}\text { I } \\
\text { II }\end{array}$ & $\begin{array}{l}12(24 \%) \\
38(76 \%)\end{array}$ & $\begin{array}{l}19(38 \%) \\
31(62 \%)\end{array}$ & $\begin{array}{l}15(30 \%) \\
35(70 \%)\end{array}$ & 0.313 \\
\hline
\end{tabular}

Group I: $0.500 \%$ - Group II: 0.375\% - Group III: $0.250 \%$

Among the groups; It was found that there was a statistically significant difference between onset times of sensory block and motor block $(p<0.001)$. Multiple comparison tests (post-hoc) were applied to find out which groups differed. The onset of sensory and motor block were significantly delayed in the Group III than the other groups $(\mathrm{P}<0.001)$ (Table III).

Table III. Comparison of sensory and motor block onset times in groups [Mean \pm SD - Median (Min/Max)]

\begin{tabular}{lcccc}
\hline & $\begin{array}{c}\text { Group I } \\
(\mathbf{n}=50)\end{array}$ & $\begin{array}{c}\text { Group II } \\
(\mathbf{n}=\mathbf{4 6 )}\end{array}$ & $\begin{array}{c}\text { Group III } \\
(\mathbf{n}=\mathbf{4 6 )}\end{array}$ & $\mathbf{p}$ \\
\hline SB onset time & $7.5 \pm 3.1$ & $7.7 \pm 3.2$ & $9.8 \pm 2.8$ & $<0.001$ \\
& $5(5 / 15)$ & $5(5 / 15)$ & $10(5 / 15)$ & \\
MB onset time & $9.7 \pm 4.3$ & $11.2 \pm 5.3$ & $12.1 \pm 4.3$ & 0.020 \\
& $10(5 / 20)$ & $10(5 / 25)$ & $10(5 / 25)$ & \\
\hline
\end{tabular}

SB: Sensory block, MB: Motor Block

Group I: 0.500\% - Group II: 0.375\% - Group III: 0.250\%

When we compared the groups both surgical compliance time and motor block score at surgical compliance time were found statistically significant $(p<0.001)$ (Table IV). Multiple comparison tests (post-hoc) were applied to find out the groups which is responsible from intergroup difference. Group III patients had the latest surgical compliance time and the lowest motor block score at surgical compliance time.
Additional anesthetic methods were applied in 4 patients only (8\%) in Group II (2 LMA, 1 median nerve block, 1 sedation), in 4 patients (8\%) in Group III (all LMA) and additional anesthetic methods were not applied in Group I patients. Patients in need of additional anesthesia methods were excluded from the study.

The additional analgesic requirement in the first 24 hours was found to be minimum in Group I patients $(29(58 \%))$ and the most analgesic requirement was found in Group III patients (39 (78\%)). It was found that there was a statistically significant difference in the analgesic requirement time of the patients who needed analgesics within the first 24 hours $(p<0.05)$ (Table V). Analgesia was required for $18.9 \pm 4.4$ hours in Group I ( $n=29), 18.6 \pm 4.0$ hours in Group II $(n=33)$ and $16.0 \pm 6$ hours in Group III $(n=39)$. There was a statistically significant difference between Group III and the other groups. Group III patients had required earlier than the other groups.

Table IV. Comparison of motor block score between groups during Surgical Compliance Time and Surgical Compliance [Mean \pm SD - Median (Min / Max)]

\begin{tabular}{lcccc}
\hline & $\begin{array}{c}\text { Group I } \\
(\mathbf{n}=50)\end{array}$ & $\begin{array}{c}\text { Group II } \\
(\mathbf{n}=\mathbf{4 6})\end{array}$ & $\begin{array}{c}\text { Group III } \\
(\mathbf{n}=\mathbf{4 6 )})\end{array}$ & $\mathbf{p}$ \\
\hline Surgical Compliance & $20.0 \pm 5.3$ & $21.4 \pm 6.2$ & $35.0 \pm 5.7$ & $<0.001$ \\
Time & $20(10 / 35)$ & $20(10 / 35)$ & $35(20 / 45)$ & \\
& & & & \\
Motor block score at & $14.3 \pm 1.7$ & $13.9 \pm 2.2$ & $12.1 \pm 1.6$ & $<0.001$ \\
$\begin{array}{l}\text { Surgical Compliance } \\
\text { Time }\end{array}$ & $14(11 / 16)$ & $14(8 / 16)$ & $12(8 / 15)$ & \\
\hline
\end{tabular}

Group I: $0.500 \%$ - Group II: 0.375\% - Group III: 0.250\%

Table V. Comparison of analgesic requirement status between groups

\begin{tabular}{llcccc}
\hline & & Group I & Group II & Group III & p \\
\hline Analgesic & No & $21(42 \%)$ & $14(30 \%)$ & $7(15 \%)$ & \\
Requirement & Yes & $29(58 \%)$ & $32(70 \%)$ & $39(85 \%)$ & 0.016
\end{tabular}

Group I: 0.500\% - Group II: 0.375\% - Group III: 0.250\%

\section{DISCUSSION}

In this double-blinded, randomized, prospective study, we compared 3 concentrations of bupivacaine using the same total volume for ultrasound-guided infraclavicular block in the upper extremity surgery. The onset of sensory block, motor block and SCT were significantly longer in the $0.25 \%$ bupivacaine 
group than the other groups ( $\mathrm{p} \leq 0.05)$. Motor block score at SCT was also lower in the $0.25 \%$ bupivacaine group. The earliest sensory-motor block regression time and analgesic necessity were detected in the $0.25 \%$ bupivacaine group.

In the literature, researchers showed that manipulation of volume or concentration can affect the nerve block. In the studies that compared the different volume/concentration combinations for sciatic nerve blocks shorter onset times with a higher concentration/lower volume of LA compared with a higher volume/lower concentration have been observed ${ }^{(15,16)}$. In another study it was found that higher volume and lower concentration provided faster motor block of axillary nerve compared with a lower volume/higher concentration ${ }^{(17)}$.

In our study, successful blocks were obtained in all groups. Although there was no statistical significance, the need for additional anesthetic methods was observed as the concentration decreased. Decreasing the concentration using a fixed volume in our study reduced the local anesthetic dose. The volume of all groups were $20 \mathrm{~mL}$. In recent US-guided infraclavicular block study which showed that increasing the lidocaine concentration from $1 \%$ to $1.5 \%$ or $2 \%$ failed to impact the onset time of the block. Their smallest volume was $26.25 \mathrm{~mL}$ in the $2 \%$ group which resulted in the lowest duration of complete motor block of the musculocutaneous nerve ranged from 15 to 30 minutes ${ }^{(18)}$. When we compared these two studies, in our study the volume of the local anesthetic was smaller.

Blocks made in a limited area such as plexus blocks are reduced using a suitable volume concentration can be achieved with lower local anesthetic dose successful block. Moreover, the use of lower concentrations may decrease the postoperative motor block time, which may be more comfortable for some patients.

In many studies it has been acknowledged that increased concentration causes decreased block onset time and increased motor and sensory block quality ${ }^{(15,16)}$. However, equivalent volume and different concentrations can affect block quality. According to the results obtained decreasing the concentration of bupivacaine from $0.5 \%$ to $0.375 \%$, and then to $0.25 \%$, means that the onset of sensory block is significantly prolonged during surgery and time to regression of the block is decreased which causes the need for analgesic use earlier in the postoperative period.

The motor block score is low when a sufficient sensory block is provided for surgery in the $0.25 \%$ concentration group. Sensory and motor block regression times are also decreased. Although $0.25 \%$ bupivacaine concentration is disadvantageous as a result of this treatment, it may be preferred in the patient groups in which full motor block is not wanted due to effective sensory blockage, after which motor activity examination and physical therapy are planned relatively earlier.

As the limitation of our study; we used 3 different concentrations but the same commonly used volume of bupivacaine. However it is not possible to determine the maximal, and minimum longevities of block obtained without determining the minimum effective concentration of bupivacaine.

As a result of our study, US-guided infraclavicular brachial plexus block application with 0.5, 0.375 and $0.25 \%$ bupivacaine concentrations in $20 \mathrm{~mL}$ volume can be performed effectively in forearm and hand surgeries. However, when drug concentration is reduced in block-inducing bupivacaine administered in equivalent volume, the prolongation of the block onset time occurs after a certain drop in concentration. In order to determine this concentration there is a need for further long-term multi-centered studies conducted with greater number of patients.

Ethics Committee Approval: Ankara Numune Training and Research Hospital Ethics Committee approval was obtained (25.11.2015/E-15-667)

Conflict of Interest: None.

Funding: None.

Informed Consent: The patients' consent were obtained.

Etik Kurul Onayı: Ankara Numune Eğitim ve Araştırma Hastanesi Klinik Araştırmalar Etik Kurulu onayı alınmıştır (25.11.2015/E-15-667)

Çıkar Çatışması: Yoktur. Finansal Destek: Yoktur.

Hasta Onamı: Hastaların onamı alındı. 


\section{REFERENCES}

1. Murphy, Damian B, Chan VWS. Upper Extremity Bloks for Day Surgery. Tech Reg Anesth Pain Manag. 2000;4:166. https://doi.org/10.1016/S1084-208X(00)70010-3

2. E. M, Gregg C, Larijani GE, et al. Anesthesiology. [American Society of Anesthesiologists, etc.], http://anesthesiology. pubs. asahq.org/article. aspx?articleid=1954176 (1987, accessed 14 August 2018).

3. Rodríguez J, Bárcena M, Taboada-Mu-iz M, et al. A Comparison of Single Versus Multiple Injections on the Extent of Anesthesia with Coracoid Infraclavicular Brachial Plexus Block. Anesth Analg. 2004;99:1225-30. https://doi.org/10.1213/01.ANE.0000131724.73956.8E

4. Rodríguez J, Bárcena M, Lagunilla J, et al. Increased success rate with infraclavicular brachial plexus block using a dual-injection technique. J Clin Anesth. 2004;16:251-6. https://doi.org/10.1016/j.jclinane.2003.08.006

5. Ting PL, Sivagnanaratnam V. Ultrasonographic study of the spread of local anaesthetic during axillary brachial plexus block. Br J Anaesth. 1989;63:326-9. https://doi.org/10.1093/bja/63.3.326

6. Rodríguez J, Taboada-Mu-iz $\mathrm{M}$, Bárcena $\mathrm{M}$, et al. Median versus musculocutaneous nerve response with single-injection infraclavicular coracoid block. Reg Anesth Pain Med. 2004;29:534-8. https://doi.org/10.1097/00115550-200411000-00005

7. Tran DQH, Russo G, Mu-oz L, et al. A Prospective, Randomized Comparison Between Ultrasound-Guided Supraclavicular, Infraclavicular, and Axillary Brachial Plexus Blocks. Reg Anesth Pain Med. 2009;34:366-71. https://doi.org/10.1097/AAP.0b013e3181ac7d18

8. Covino BG. Pharmacology of local anaesthetic agents. Br J Anaesth. 1986;58:701-16.

https://doi.org/10.1093/bja/58.7.701

9. Eisenach JC. Regional anesthesia: advancing the practice of medicine; the 2008 Gaston Labat Award lecture. Reg Anesth Pain Med. 2008;33:463-9. https://doi.org/10.1097/00115550-200809000-00010

10. Takeda A, Ferraro LHC, Rezende AH, et al. Minimum effective concentration of bupivacaine for axillary brachial plexus block guided by ultrasound. Brazilian J Anesthesiol. English Ed 2015;65:163-9.

https://doi.org/10.1016/j.bjane.2013.11.007

11. Liu SS, Ngeow J, John RS. Evidence Basis for UltrasoundGuided Block Characteristics. Reg Anesth Pain Med. 2010;35:26-35. https://doi.org/10.1097/AAP.0b013e3181d266f0

12. O'Donnell BD, lohom G. An Estimation of the Minimum Effective Anesthetic Volume of $2 \%$ Lidocaine in Ultrasound-guided Axillary Brachial Plexus Block. Anesthesiology. 2009;111:25-9. https://doi.org/10.1097/ALN.0b013e3181a915c7

13. Eren G, Altun E, Pektas $Y$, et al. To what extent can local anesthetics be reduced for infraclavicular block with ultrasound guidance? Anaesthesist. 2014;63:760-5. https://doi.org/10.1007/s00101-014-2361-4

14. Brattwall $M$, Jildenstål $P$, Warrén Stomberg $M$, et al. Upper extremity nerve block: how can benefit, duration, and safety be improved? An update. F1000Research 2016;5:907. https://doi.org/10.12688/f1000research.7292.1

15. Smith BE, Siggins D. Low volume, high concentration block of the sciatic nerve. Anaesthesia. 1988;43:8-11. https://doi.org/10.1111/j.1365-2044.1988.tb05413.x

16. Mu-iz MT, Rodríguez J, Bermúdez M, et al. Low Volume and High Concentration of Local Anesthetic Is More Efficacious than High Volume and Low Concentration in Labat's Sciatic Nerve Block: A Prospective, Randomized Comparison. Anesth Analg. 2008;107:2085-8.

https://doi.org/10.1213/ane.0b013e318186641d

17. Krenn H, Deusch E, Balogh B, et al. Increasing the injection volume by dilution improves the onset of motor blockade, but not sensory blockade of ropivacaine for brachial plexus block. Eur J Anaesthesiol. 2003;20:21-5. https://doi.org/10.1097/00003643-200301000-00004

18. González AP, Bernucci F, Techasuk W, et al. A randomized comparison between 3 combinations of volume and concentration of lidocaine for ultrasound-guided infraclavicular block. Reg Anesth Pain Med. 2013;38:206-11. https://doi.org/10.1097/AAP.0b013e318287fe53 